\title{
PENGARUH MODEL PROBLEM BASED LEARNING DENGAN METODE EKSPERIMEN TERHADAP HASIL BELAJAR IPA FISIKA SISWA KELAS VII SMP NEGERI 19 MATARAM TAHUN PELAJARAN 2014/2015
}

\author{
Nurqomariah ${ }^{1}$, Gunawan $^{2}$, Sutrio $^{2}$ \\ 1) Program Studi Pendidika Fisika \\ 2) Program Studi Pendidika Fisika FKIP \\ Universitas Mataram \\ Mataram, Indonesia \\ Email: qomariah.nur22@gmail.com
}

\begin{abstract}
This research is a quasi-experimental aims to find the impact of problem based learning model with experimental methods on the learning outcomes physics science of grade VII SMPN 19 Mataram in academic year 2014/2015. The population of this research is students of grade VII SMPN 19 Mataram with 144 students, while the sampling of this research is grade as VIIA as experimental group and VIIB as the control group. The sampling technique used is purposive sampling. The research design used is untreated control group design with pretest and posttest. Pre-test results obtained by the average value of experimental group is 25.36 while the control group is 28.54 . Post-test results for experimental group is 75.13 , while for the control group is 65.41 . Research hypotheses were analyzed by t-test two tail using formulas polled variance t-test given the result that thint is greater than ttable, In addition, an increase on learning outcomes analyzed using $\mathrm{N}$-gain test given the result that experimental group has increased higher than the control group.so that can be concluded that the model of problem-based learning with experimental method given positive impact on learning outcomes physics science of grade VII SMPN 19 Mataram in academic year 2014/2015.
\end{abstract}

\section{Keywords: Problem Based Learning Model, Experimental Methods, Learning Outcomes}

\section{Pendahuluan}

Ilmu pengetahuan alam atau disingkat IPA merupakan ilmu yang mempelajari sesuatu yang berkaitan dengan alam. IPA di Sekolah Menengah Pertama (SMP) terdiri dari beberapa cabang ilmu diantaranya Fisika, Kimia, dan Biologi yang menyatu dalam mata pelajaran IPA terpadu. IPA pada hakikatnya merupakan suatu produk, proses dan sikap. Sebagai produk, IPA merupakan hasil penemuan dari berbagai kegiatan penyelidikan atau penelitian yang berupa fakta, konsep, prinsip, hukumhukum dan teori ataupun model. Sebagai suatu proses, IPA merupakan proses untuk menemukan, mengembangkan dan menguji informasi ilmiah yang telah diperoleh. IPA sebagai sikap diartikan sebagai proses penemuan, pengamatan, pengukuran, dan penyelidikan ilmiah yang dilakukan memerlukan proses mental dan sikap yang berasal dari suatu pemikiran yang ilmiah [1].

Fisika sebagai salah satu cabang dari IPA yang mempelajari gejala-gejala alam dan peristiwa alam baik yang dapat dilihat maupun yang bersifat abstrak. Pembelajaran IPA fisika bukan hanya untuk menguasai sejumlah pengetahuan sebagai produk IPA fisika, tetapi juga harus menyediakan ruang yang cukup untuk tumbuh dan berkembangnya sikap ilmiah, berlatih melakukan proses pemecahan masalah, dan penerapan IPA fisika dalam kehidupan nyata karena salah satu tujuan dari pembelajaran IPA fisika yaitu siswa diharapkan dapat mengkonstruksi pengetahuannya dalam pikirannya dan bekerja memecahkan masalah agar siswa dapat memahami dan dapat menerapkan pengetahuannya. Hal ini menuntut keaktifan siswa selama proses pembelajaran melalui upaya siswa untuk menemukan sendiri pemecahan masalah yang mereka hadapi terkait dengan pembelajaran fisika.

Beberapa masalah yang sering ditemukan peneliti selama kegiatan Praktek Pengalaman Lapangan di SMPN 19 Mataram menemukan bahwa proses pembelajaran IPA fisika masih berpusat pada guru bukan pada siswa (teacher centered), proses pembelajaran IPA fisika hanya bergantung pada buku teks dengan metode menghafal daripada memahami konsep, padahal seharusnya pembelajaran IPA fisika sebaiknya dilaksanakan secara inkuiri untuk menumbuhkan kemampuan berpikir, bekerja dan bersikap ilmiah serta mengkomunikasikannya. Selain itu, masalah lainnya adalah siswa cenderung menjadi pembelajar yang pasif karena hanya mendengarkan penjelasan dari guru dan menyalin informasi yang diterimanya dari guru kemudian siswa mengerjakan soal-soal yang diberikan guru, sehingga membuat 
siswa bosan mengikuti proses pembelajaran. Kondisi ini berimplikasi pada hasil belajar siswa kelas VII SMPN 19 Mataram rendah yang masih berada dibawah KKM. Menyikapi permasalahan di atas, maka perlu adanya model pembelajaran yang menarik dan menyenangkan sehingga dapat meningkatkan keaktifan siswa dan mampu meningkatkan hasil belajarnya.

Salah satu alternatif solusi yang ditawarkan adalah model problem based learning. Model problem based learning adalah model pembelajaran yang bersifat student centered untuk memecahkan suatu masalah yang bisa diajukan oleh guru maupun siswa. Model ini dapat membuat siswa menjadi lebih aktif untuk mengembangkan pengetahuan yang dimilikinya. Untuk lebih memudahkan siswa dalam memecahkan masalah yang dihadapinya, maka peneliti memadukan model problem based learning dengan metode eksperimen. Metode eskperimen adalah suatu cara penyampaian pengajaran dengan melakukan kegiatan percobaan untuk membuktikan sendiri materi IPAfisika yang dipelajari. Metode eksperimen digunakan untuk melihat kemampuan siswa mengkolaborasikan antara pengetahuan dan kecakapan yang dimiliki oleh setiap siswa dalam menggunakan alat dan bahan praktikum. Sehingga dari perpaduan antara model dengan metode tersebut diharapkan dapat mempengaruhi hasil belajar siswa menjadi meningkat.

\section{TinjauAn Pustaka}

\section{A. Model Problem Based Learning dengan Metode Eksperimen}

Model problem based learning atau model pembelajaran berbasis masalah adalah model yang menekankan pada pembelajaran berbasis student centered, yang dapat memberdayakan peserta didik untuk melakukan penyelidikan, mengintegrasikan teori dan praktik, menerapkan pengetahuan dan keterampilannya untuk mengembangkan penemuan solusi atau pemecahan masalah tertentu [2]. Model problem based learning terdiri dari 5 fase pembelajaran yang meliputi: orientasi siswa terhadap masalah, organisasi siswa, membantu investigasi mandiri atau kelompok, mengembangkan dan mempresentasikan hasil, menganalisis dan mengevaluasi proses pemecahan masalah [3].

\section{B. Metode Eksperimen}

Metode eksperimen adalah suatu cara penyampaian pengajaran dengan melakukan kegiatan percobaan untuk menemukan sendiri apa yang dipelajari baik secara individu maupun kelompok, sehingga siswa mampu mengecek kebenaran suatu hipotesis atau membuktikan sendiri apa yang dipelajari [4].

\section{Hasil Belajar}

Hasil belajar adalah penguasaan produk IPA fisika yang mengacu pada perubahan kemampuan bidang kognitif yang mencakup dimensi pengetahuan dan dimensi proses kognitif yang dicapai siswa sebagai hasil dari proses pembelajaran IPA fisika yang ditempuh selama kurun waktu tertentu berdasarkan tujuan pembelajaran yang ditetapkan [5].

\section{Metode Penelitian}

Jenis penelitian ini adalah penelitian kuasi eksperimen yaitu suatu cara untuk menguji hubungan sebab, dimana peneliti memberikan perlakuan kepada subjek untuk menentukan apakah perlakuan tersebut memiliki dampak atau pengaruh pada variabel atau faktor hasil tertentu serta peneliti tidak memiliki keleluasaan untuk mengontrol variabel-variabel luar yang mempengaruhi pelaksanaan eksperimen [6]. Penelitian ini dilaksanakan dari bulan Oktober 2014 sampai dengan bulan Juli 2015 di kelas VII SMPN 19 Mataram tahun pelajaran 2014/2015. Desain penelitian menggunakan untreated control group design with pretest and postes. Adapun teknik pengambilan sampel yang digunakan adalah purposive sampling dimana pengambilan sampel dilakukan karena peneliti mempunyai alasan tertentu dalam mengambil sampel tersebut, yaitu dikarenakan kemampuan awal kedua kelas relatif sama. Dalam penelitian ini yang dijadikan sampel yaitu kelas VII $_{\mathrm{A}}$ sebagai kelas eksperimen dan $\mathrm{VII}_{\mathrm{B}}$ sebagai kelas kontrol. Pada penelitian ini ada tiga variabel yang menjadi fokus penelitian yaitu variabel bebas, variabel control, variabel terikat. Variabel bebas pada penelitian ini adalah model problem based learning dengan metode eksperimen pada kelas eksperimen dan model pembelajaran konvensional pada kelas kontrol, variabel terikat adalah hasil belajar kognitif siswa pada kelas eksperimen dan kelas kontrol, variabel kontrolnya adalah kemampuan awal siswa pada kelas eksperimen dan kelas kontrol dianggap sama, guru yang mengajar pada kelas kontrol dan kelas eksperimen sama yaitu peneliti sendiri; materi yang diajarkan pada kelas eksperimen dan kelas kontrol sama yaitu materi kalor; cara penilaian pada kelas kontrol dan kelas eksperimen sama yaitu menggunakan tes tertulis berupa tes pilihan ganda. 
Teknik pengumpulan data pada penelitian ini adalah tes hasil belajar. Data tes hasil belajar merupakan data tes awal sebelum diberikan perlakuan dan tes akhir setelah diberi perlakuan. Data tes awal dan tes akhir diperoleh dengan menggunakan instrument yang telah diujicobakan kepada 33 orang siswa kelas VIII yang sudah menerima materi kalor sebelumnya, kemudian hasil tes tersebut diukur dengan uji validitas menggunakan rumus product moment, uji reliabilitas soal menggunakan rumus Sperman-Brown, indeks kesukaran soal untuk tingkat kesukaran, dan indeks diskriminasi untuk daya beda soal. Berdasarkan hasil uji coba 30 butir soal diperoleh 22 butir soal yang baik digunakan untuk tes awal dan tes akhir. Analisis data tes akhir menggunakan uji-t dua pihak (polled varians), yang sebelumnya telah diuji homogenitas sampel menggunakan Uji-F dan normalitas data menggunakan uji Chi-Kuadrat. Sedangkan untuk mengetahui peningkatan hasil belajar siswa pada kedua kelas sampel dan pada setiap sub materi digunakan uji N-Gain.

\section{Hasil dan Pembahasan}

Hasil penelitian berupa deskripsi hasil tes awal dan tes akhir dengan menggunakan uji homogenitas, uji normalitas dan uji hipotesis (uji-t polled varians). Adapun hasil rekapitulasi nilai tes awal pada kelas eksperimen dan kelas kontrol materi kalor dapat dilihat pada tabel 1 .

Tabel 1. Rekapitulasi Nilai Tes Awal pada Kedua Kelas Sampel

\begin{tabular}{|c|c|c|}
\hline \multirow[b]{2}{*}{ Komponen } & \multicolumn{2}{|c|}{ Kemampuan Awal } \\
\hline & $\begin{array}{c}\text { Kelas } \\
\text { Eksperimen }\end{array}$ & $\begin{array}{c}\text { Kelas } \\
\text { Kontrol }\end{array}$ \\
\hline Jumlah siswa & 33 & 35 \\
\hline Nilai tertinggi & 36 & 45 \\
\hline Nilai terendah & 9 & 18 \\
\hline Rata-rata & 25,36 & 28,54 \\
\hline Standar Deviasi & 8,91 & 7,82 \\
\hline Uji Homogenitas & \multicolumn{2}{|c|}{ Homogen } \\
\hline Uji Normalitas & Normal & Normal \\
\hline
\end{tabular}

Data hasil penelitian menunjukkan bahwa nilai rata-rata tes awal siswa pada kedua sampel sebesar 25,36 untuk kelas eksperimen dan 28,54 untuk kelas kontrol. Pada tabel 1, menunjukkan bahwa kelas eksperimen dan kelas kontrol homogen yang berarti kedua kelas sampel memiliki kemampuan awal yang sama. Selain itu, hasil rata-rata tes awal yang rendah disebabkan karena siswa pada kedua kelompok sampel belum mendapatkan pembelajaran mengenai materi kalor. Oleh karena itu, siswa belum memiliki pemahaman yang memadai untuk menjawab soal-soal tes awal yang diberikan.

Setelah dilakukan tes awal selanjutnya kedua kelas sampel diberi perlakuan yang berbeda, dimana kelas eksperimen diberikan perlakuan model problem based learning dengan metode eksperimen sedangkan kelas kontrol diberikan perlakuan model pembelajaran konvensional. Berdasarkan hasil tes akhir siswa terjadi peningkatan nilai rata-rata tes akhir dari nilai rata-rata tes awal seperti yang terlihat pada tabel 2.

Tabel 2. Rekapitulasi Nilai Tes Akhir pada Kedua Kelas Sampel

\begin{tabular}{|c|c|c|}
\hline \multirow[b]{2}{*}{ Komponen } & \multicolumn{2}{|c|}{ Kemampuan Akhir } \\
\hline & $\begin{array}{c}\text { Kelas } \\
\text { Eksperimen }\end{array}$ & $\begin{array}{c}\text { Kelas } \\
\text { Kontrol }\end{array}$ \\
\hline Jumlah siswa & 24 & 27 \\
\hline Nilai tertinggi & 86 & 82 \\
\hline Nilai terendah & 59 & 55 \\
\hline Rata-rata & 75,13 & 65,41 \\
\hline Standar Deviasi & 8,88 & 8,67 \\
\hline Uji Homogenitas & \multicolumn{2}{|c|}{ Homogen } \\
\hline Uji Normalitas & Normal & Normal \\
\hline Uji Hipotesis & $\begin{array}{r}\mathrm{t}_{\text {hitung }}>\mathrm{t}_{\mathrm{t}} \\
\text { dan } \mathrm{F}\end{array}$ & $\begin{array}{l}\mathrm{H}_{0} \text { ditolak } \\
\text { erima }\end{array}$ \\
\hline
\end{tabular}

Pada kelas eksperimen dan kontrol setelah diberikan perlakuan, terjadi peningkatan hasil belajar IPA fisika siswa. Nilai rata-rata tes akhir siswa kelas eksperimen adalah 75,13 sedangkan nilai rata-rata siswa kelas kontrol adalah 65,41. Hasil tes akhir pada kedua kelas sampel menunjukkan suatu perbedaan yang signifikan, peningkatan nilai rata-rata tes akhir siswa kelas eksperimen menunjukkan peningkatan yang lebih tinggi daripada siswa kelas kontrol. Hal ini sesuai dengan penelitian yang yang menyatakan bahwa dengan menerapkan model pembelajaran berbasis masalah (problem based learning) dapat meningkatkan hasil belajar siswa yang lebih baik dibandingkan dengan hasil belajar siswa yang diajarkan dengan model pembelajaran konvensional [7].

Berdasarkan hasil uji hipotesis dengan menggunakan uji-t dua pihak menggunakan data tes akhir kedua kelas sampel menunjukkan bahwa nilai $t_{\text {hitung }}=3,95$ lebih besar dari $t_{\text {tabel }}=2,01$. Hal ini berarti $\mathrm{H}_{0}$ ditolak, sehingga dapat disimpulkan bahwa terdapat pengaruh model problem based learning dengan metode eksperimen terhadap hasil belajar IPA 
fisika siswa kelas VII SMPN 19 Mataram tahun pelajaran 2014/2015. Hal ini sejalan dengan hasil penelitian yang menyatakan bahwa model pembelajaran berbasis masalah (problem based learning) berpengaruh terhadap hasil belajar fisika siswa [8]. Selain itu, penelitian yang berkaitan dengan penerapan model problem based learning dengan metode eksperimen menunjukkan hasil bahwa penerapan problem based learning melalui metode praktikum (eksperimen) berpengaruh terhadap hasil belajar siswa [9].

Hasil belajar IPA fisika siswa pada kedua kelas sampel dianalisis juga menggunakan rumus $N$-gain untuk mengetahui persentase peningkatan hasil belajar IPA fisika yang diperoleh dari nilai rata-rata masing-masing kelas sampel. Kelas eksperimen mengalami peningkatan hasil belajar IPA fisika sebesar $67 \%$ sedangkan kelas kontrol mengalami peningkatan sebesar 52\%. Berdasarkan hasil analisis tersebut dapat disimpulkan bahwa hasil belajar IPA fisika pada kelas eksperimen mengalami peningkatan yang lebih besar dibandingkan kelas kontrol. Hal ini disebabkan karena pembelajaran dengan menggunakan model problem based learning dengan metode eksperimen pada kelas eksperimen tinggi mampu membuat siswa menjadi lebih bersemangat dan fokus terhadap materi yang dipelajari karena pembelajarannya berkaitan dengan masalah fisika dalam kehidupan sehari-hari yang membuat siswa menjadi lebih aktif karena siswa mencoba mencari tahu sendiri solusi dari permasalahan tersebut melalui kegiatan eksperimen sehingga pengetahuan yang diperoleh dapat lebih dipahami dan diingat dalam jangka panjang. Berbeda dengan pembelajaran pada kelas kontrol yang membuat siswa pasif karena memperoleh informasi dari penjelasan peneliti dan buku-buku pelajaran sehingga pengetahuan yang diperoleh siswa hanya bersifat sementara. Hal ini menunjukkan bahwa siswa pada kelas eksperimen dengan penerapan model problem based learning dengan metode eksperimen mengalami hasil belajar kognitif yang tinggi dibandingkan pada kelas kontrol dengan penerapan pembelajaran konvensional. Penelitian sebelumnya menunjukkan bahwa penerapan model pembelajaran berbasis masalah (problem based learning) dapat meningkatkan hasil belajar kognitif siswa [10].

Peningkatan hasil belajar IPA fisika juga dianalisis pada setiap sub materi kalor. Analisis persentase peningkatan hasil belajar IPA fisika tiap sub materi kalor menggunakan uji N-gain tersaji pada tabel 3.
Tabel 3. Persentase Peningkatan Hasil Belajar IPA Fisika Tiap Sub Materi pada Kedua Sampel

\begin{tabular}{|c|c|c|}
\hline \multirow[b]{2}{*}{ Sub Materi } & \multicolumn{2}{|c|}{ N-Gain } \\
\hline & $\begin{array}{c}\text { Kelas } \\
\text { Eksperimen }\end{array}$ & $\begin{array}{c}\text { Kelas } \\
\text { Kontrol }\end{array}$ \\
\hline Definisi Kalor & $89 \%$ & $42 \%$ \\
\hline $\begin{array}{l}\text { Pengaruh Kalor } \\
\text { terhadap Suhu } \\
\text { Benda }\end{array}$ & $59 \%$ & $61 \%$ \\
\hline $\begin{array}{l}\text { Pengaruh Kalor } \\
\text { terhdap Wujud Zat }\end{array}$ & $77 \%$ & $23 \%$ \\
\hline Penguapan & $72 \%$ & $47 \%$ \\
\hline Azas Black & $37 \%$ & $61 \%$ \\
\hline Perpindahan Kalor & $90 \%$ & $41 \%$ \\
\hline
\end{tabular}

Pada sub materi definisi kalor, kelas eksperimen menunjukkan peningkatan hasil belajar IPA fisika sebesar $89 \%$ sedangkan kelas kontrol sebesar $42 \%$, sehingga dapat disimpulkan bahwa kelas eksperimen mengalami peningkatan hasil belajar IPA fisika yang lebih tinggi dibandingkan kelas kontrol pada sub materi definisi kalor. Hal ini dikarenakan sub materi definisi kalor yang diajarkan pada kelas eksperimen menggunakan suatu permasalahan yang diselesaikan melalui eksperimen sederhana untuk menemukan konsep yang berkaitan dengan definisi kalor. Hal ini merupakan salah satu kelebihan model problem based learning dengan metode eksperimen yaitu siswa lebih memahami konsep yang diajarkan lantaran siswa yang menemukan konsep tersebut [11].

Pada sub materi pengaruh kalor terhadap wujud zat dan sub materi penguapan, hasil analisis menunjukkan bahwa peningkatan hasil belajar IPA fisika siswa pada kelas eksperimen lebih tinggi dibandingkan dengan kelas kontrol. Persentase uji $\mathrm{N}$ gain pada kelas eksperimen sebesar $77 \%$ sedangkan pada kelas kontrol sebesar 23\%. Kemudian hasil analisis pada sub materi penguapan menunjukkan bahwa peningkatan hasil belajar IPA fisika kelas eksperimen sebesar $72 \%$ sedangkan kelas kontrol sebesar $47 \%$. Perbedaan peningkatan yang signifikan ini disebabkan karena pada saat proses pembelajaran sub materi pengaruh kalor terhadap wujud zat dan sub materi penguapan siswa sangat antusias dan bersemangat melakukan percobaan untuk mencari solusi dari suatu permasalahan melalui eksperimen sehingga menemukan konsep tentang pengaruh kalor terhadap wujud zat dan penguapan. Hal tersebut membuat siswa lebih mengingat konsep dari solusi permasalahan yang mereka temukan sendiri.

Pada sub materi perpindahan kalor menunjukkan peningkatan hasil belajar IPA fisika tertinggi. Hasil 
analisis menunjukkan bahwa peningkatan kelas eksperimen sebesar 90\% sedangkan kelas kontrol sebesar $41 \%$. Perbedaan peningkatan yang signifikan ini berati pengetahuan yang diperoleh pada proses pembelajaran sangat baik. Pada saat proses pembelajaran fase ke-3 membantu penyelidikan mandiri ataupun kelompok siswa sangat aktif dalam menemukan solusi permasalahan melalui percobaan. Sehingga siswa pada kelas eksperimen cenderung lebih mudah memahami konsep-konsep yang dipelajarinya karena siswa menemukan sendiri konsep-konsep tersebut melalui kegiatan percobaan untuk memecahkan suatu permasalahan yang berkaitan dengan materi perpindahan kalor, sehingga siswa lebih mudah memahami dan mengingatnya. Hal ini merupakan salah satu keunggulan model problem based learning bahwa pengetahuan tertanam berdasarkan skemata yang dimiliki oleh siswa sehingga pembelajaran lebih bermakna [12]. Selain itu, penelitian sebelumnya yang mendukung penelitian ini menunjukkan bahwa penerapan metode eksperimen mempunyai pengaruh lebih baik terhadap hasil belajar siswa pada materi perpindahan kalor [13].

Kelas eksperimen tidak mengalami peningkatan yang signifikan dibandingkan kelas kontrol pada sub materi pengaruh kalor terhadap suhu benda dan sub materi azas Black. Pada sub materi pengaruh kalor terhadap suhu benda, hasil analisis data menunjukkan bahwa peningkatan hasil belajar IPA fisika pada kelas eksperimen sebesar 59\% sedangkan pada kelas kontrol sebesar $61 \%$. Hal ini menunjukkan bahwa peningkatan kelas kontrol lebih tinggi dari kelas eksperimen. Kemudian pada sub materi azas Black, hasil analisis $\mathrm{N}$-gain pada kelas eskperimen menunjukkan peningkatan sebesar $37 \%$ sedangkan kelas kontrol sebesar $61 \%$. Hal ini disebabkan pada sub materi pengaruh kalor terhadap suhu benda dan azas Black tidak hanya berisi konsep yang ditemukan melalui eksperimen untuk menemukan solusi suatu permasalahan melainkan siswa juga harus menyelesaikan suatu persamaan matematis untuk menentukan suatu nilai. Siswa pada kelas kontrol lebih banyak berlatih menyelesaikan suatu persamaan matematis yang berkaitan dengan sub-sub materi tersebut sedangkan siswa pada kelas eksperimen kurang berlatih menyelesaikan suatu persamaan matematis yang berkaitan dengan sub-sub materi tersebut karena waktu pembelajaran lebih banyak untuk melakukan eksperimen. Hal ini merupakan salah satu kelemahan model problem based learning yaitu membutuhkan banyak waktu dan tidak semua materi dapat diterapkan dengan model dan metode ini [13].

Berdasarkan hasil pembahasan di atas, maka dapat ditarik suatu generalisasi bahwa model problem based learning dengan metode eksperimen berpengaruh terhadap hasil belajar IPA Fisika siswa kelas VII SMP Negeri 19 Mataram Tahun Pelajaran 2014/2015. Hasil belajar IPA fisika berdasarkan nilai rata-rata pada kelas eksperimen menagalami peningkatan yang lebih tinggi dibandingkan pada kelas kontrol. Penerapan model problem based learning dengan metode eksperimen menunjukkan peningkatan yang signifikan hanya pada sub materi yang berupa penguasaan konsep sedangkan pada sub materi yang berisi penyelesaian persamaan matematis kurang mengalami peningkatan yang signifikan.

Beberapa hambatan yang dihadapai peneliti ketika melakukan kegiatan penelitian, diantaranya mengenai pengaturan waktu belajar. Pembelajaran model problem based learning dengan metode eksperimen memerlukan pengaturan waktu belajar yang tepat untuk setiap fasenya. Namun hal tersebut kurang terlaksana dengan baik dalam penelitian ini. Adapun faktor yang menyebabkannya diantaranya siswa yang belum terbiasa dengan kegiatan praktikum sehingga peneliti memerlukan waktu yang lebih lama untuk membantu dan memonitoring kegiatan praktikum, akibatnya keterlaksanaan pembelajaran yang seharusnya diberlakukan menjadi kurang maksimal. Hal ini menunjukkan bahwa untuk menggunakan pembelajaran model problem based learning dengan metode eksperimen memerlukan keterampilan pengelolaan waktu yang lebih baik sehingga tujuantujuan pembelajaran yang direncanakan dapat tercapai secara tuntas. Selain itu karakteristik siswa yang berbeda-beda, terdapat siswa yang masih sibuk sendiri dan menganggu teman kelas saat proses pembelajaran berlangsung sehingga membuat suasana kelas menjadi gaduh.

\section{Penutup}

Penerapan model problem based learning dengan metode eksperimen berpengaruh positif terhadap hasil belajar IPA Fisika siswa kelas VII SMP Negeri 19 Mataram Tahun Pelajaran 2014/2015. Selain itu, kelas eksperimen dengan model problem based learning dengan metode eksperimen menunjukkan peningkatan hasil belajar IPA fisika yang lebih tinggi dibandingkan kelas kontrol dengan model pembelajaran konvensional. Penerapan model problem based learning dengan metode eksperimen menunjukkan peningkatan yang signifikan pada sub 
materi penguasaan konsep sedangkan pada sub materi penyelesaian persamaan matematis untuk menentukan suatu nilai kurang menunjukkan peningkatan yang signifikan.

Adapun saran-saran yang dapat diberikan bagi guru IPA fisika adalah seyogyanya model problem based learning dengan metode eksperimen dapat menjadi alternatif model pembelajaran yang dapat diterapkan oleh guru dalam mengajarkan IPA Fisika. Dalam menerapkan seyogyanya memperhatikan beberapa hal, yaitu: materi yang akan diajarkan; alokasi waktu sebaiknya diatur sebaik mungkin sehingga tiap tahapan pembelajaran dapat berlangsung secara optimal; memerlukan perencanaan dan persiapan yang matang sebelum diterapkan di kelas agar proses pembelajaran dapat berjalan sesuai dengan tujuan pembelajaran yang hendak dicapai; karakteristik dari siswa; teknik pengelolaan kelas. Bagi peneliti lain yang ingin meneliti penerapan model problem based learning dengan metode eksperimen sebaiknya mempersiapkan semua instrumen dengan matang serta menerapkannya pada materi yang berbeda.

\section{UCAPAN TERIMA KASIH}

Terima kasih yang sebesar-besarnya, penulis sampaikan kepada Bapak Dr. H. Wildan, M.Pd., Bapak Dr. Karnan, M.Pd., Bapak Dr. Ahmad harjono, S.Si., M.Pd., Bapak I Made Dewa Arimbawa, S.Pd., Ibu Dra. Ida Ayu Putu Armyani serta semua pihak lain yang telah membantu penelitian ini.

\section{REFERENSI}

[1] Prasetyo, Z.K. Wahyana, Mundilarto, Subiakto, dan Abdullah, A.A. (2004). Materi Pokok Kapita Selekta Pembelajaran Fisika. Jakarta: Universitas Terbuka.

[2] Savery, J.R. (2006). "Overview of Problem Based Learning : Definitions and Distinctions". Interdisciplinary Journal of Problem Based Learning (1) 9-20.

[3] Arends, R.I. (2008). Learning to Teach., Terjemahan Helly Prajitno \& Sri Mulyantini. Yogyakarta : Pustaka Pelajar.

[4] Sartika, S.B. (2012). "Pengaruh Penerapan Metode Eksperimen Sebagai Implementasi Kurikulum Tingkat Satuan Pendidikan ( KTSP ) Terhadap Prestasi Belajar Siswa”. Jurnal Pedagogia (2) 189-211.

[5] Anderson et al. (2001). A Taxonomy for Learning, Teaching, and Assessing: A Revision of
Bloom's Taxonomy of Educational Objectives. New York : Longman.

[6] Setyosari, P. (2013). Metode Penelitian Pendidikan dan Pengembangan. Jakarta: Kencana Prenada Media Group.

[7] Sihotang, D.M.I. (2013). "Pengaruh Model Pembelajaran Berbasis Masalah Terhadap Hasil belajar Siswa pada Materi Pokok Optik Geometri Kelas X SMA St. Yoseph Medan", dalam Prosiding Semirata FMIPA Universitas Lampung : Lampung.

[8] Listiawati, W., Gunawan \& Sutrio. (2015). "Pengaruh model Pembelajaran Berbasis Masalah Berbantuan Simulasi Interaktif Terhadap Hasil Belajar Fisika Siswa Kelas VIII SMPN 1 Pujut Tahun pelajaran 2013/2014". Jurnal Pendidikan Fisika dan Teknologi (1) 82-86.

[9] Zaenuddin, A. 2013. Pengaruh Pembelajaran Berbasis Masalah Melalui Metode Praktikum Terhadap Hasil Belajar Fisika Siswa Kelas X SMAN 1 Janapria Tahun Ajaran 2012/2013. Skripsi pada Prodi Pendidikan Fisika. Universitas Mataram : tidak Diterbitkan.

[10] Kharida, L.A., Rusilowati A., \& Pratiknyo K. 2009. Penerapan Model Pembelajaran Berbasis Masalah untuk Peningkatan Hasil Belajar Siswa pada Pokok Bahasan Elastisitas Bahan. Jurnal Pendidikan Fisika Indonesia Vol.5, Hal. 83-89.

[11] Jauhar, M. 2011. Implementasi Paikem dari Behavioristik sampai Konstruktivistik. Jakarta: Prestasi Pustaka.

[12] Sartika, S.B. (2012). "Pengaruh Penerapan Metode Eksperimen Sebagai Implementasi Kurikulum Tingkat Satuan Pendidikan ( KTSP ) Terhadap Prestasi Belajar Siswa". Jurnal Pedagogia (2) 189-211.

[13] Putra, S.R. (2013). Desain Belajar Mengajar Kreatif Berbasis Sains. Jogyakarta : DIVA Press.

\section{Biografi Penulis}

Nurqomariah, lahir di Bolo Kabupaten Bima tanggal 22 Februari 1993. Penulis menyelesaikan pendidikan di SDN 1 Bolo, SMPN 1 Madapangga, dan SMAN 1 Madapangga. Kemudian melanjutkan studinya di Universitas Mataram pada FKIP mengambil Program Studi Pendidikan Fisika (Lulus 2015). 